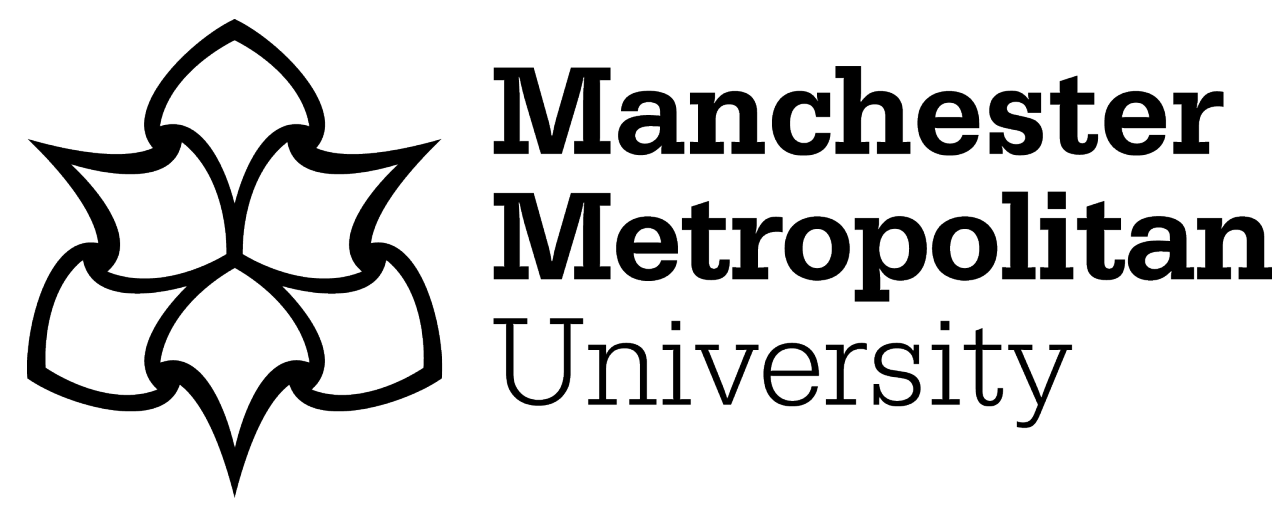

Najafi-Tavani, S, Najafi-Tavani, Z, Naudé, P, Oghazi, P and Zeynaloo, E (2018) How collaborative innovation networks affect new product performance: Product innovation capability, process innovation capability, and absorptive capacity. Industrial Marketing Management, 73. pp. 193-205. ISSN 0019-8501

Downloaded from: https://e-space.mmu.ac.uk/620467/

Publisher: Elsevier

DOI: https://doi.org/10.1016/j.indmarman.2018.02.009

Usage rights: Creative Commons: Attribution-Noncommercial-No Derivative Works 4.0

Please cite the published version 
How Collaborative Innovation Networks Affect New Product Performance: Product Innovation Capability, Process Innovation Capability, and Absorptive Capacity

\author{
Saeed Najafi-Tavani
}

Management Division, Institute for Management and Planning Studies, Tehran, Iran

Zhaleh Najafi-Tavani

University of Leeds Management School, Leeds, United Kingdom

\begin{abstract}
Peter Naudé
Manchester Metropolitan University Business School, Manchester, U.K.

University of Sydney Business School, Sydney, Australia
\end{abstract}

Pejvak Oghazi

School of Social Sciences, Sodertorn University, Stockholm, Sweden

Elham Zeynaloo

Management School, Islamic Azad University, Tehran, Iran 


\title{
How Collaborative Innovation Networks Affect New Product Performance: Product Innovation Capability, Process Innovation Capability, and Absorptive Capacity
}

\begin{abstract}
The current literature has investigated the direct relationship between collaborative innovation networks and new product performance, but the results are inconsistent. This research aims to explore the role of product and process innovation capabilities as two distinct mechanisms through which collaborative innovation networks improve new product performance. The study also examines the contingent effects of absorptive capacity on the relationship between collaborative innovation networks and the two innovation capability dimensions (i.e. product and process innovation). Survey data from 258 respondents from the Iranian high and medium technology manufacturing industries indicates the need for caution when developing collaborative innovation networks. We found that the effects of collaborative innovation networks on either product or process innovation capability are significant only in the presence of absorptive capacity. This finding suggests that the level of collaboration with different partners can enhance firms' innovation capabilities only if the focal firm's managers have developed the capacity to scan and acquire external knowledge. Our analyses further indicate that in the presence of absorptive capacity, only collaboration with research organizations and
\end{abstract}


competitors have a positive effect on product innovation capability. In the case of process innovation capability, collaboration with research organizations and suppliers are the most important factors.

Keywords: New product performance, absorptive capacity, collaborative innovation networks, innovation capability

\section{Introduction}

In an increasingly global and competitive business environment, firms have recognized the necessity of investing in new product development (NPD) to survive and gain competitive advantage (Gonzalez-Zapatero et al., 2016; Mu et al., 2017; Najafi-Tavani et al., 2013). NPD is, however, argued to be a resource intensive and expensive process associated with high risk (Liang et al., 2014). Earlier studies have identified various internal (e.g. innovation capability) and external resources and capabilities (e.g. collaboration with channel members and absorptive capacity) as drivers of NPD success (La Rocca et al., 2016; Menguc \& Auh, 2010; Mu et al., 2017; Tsai, 2009).

Collaboration with different external actors such as suppliers, customers, competitors, and research organizations (e.g. universities) improves both knowledge sharing and market knowledge acquisition by the firm, resulting in expansion of the firm's existing knowledge base, which in turn advances a firm's innovation capability (Zhou \& Li, 2012). Such collaboration has been identified in the literature as one of the most important external predictors of NPD performance (Alexiev et al., 2016; Clauss \& Kesting, 2017; Heirati et al., 2016). In this paper, the term 'collaborative innovation networks' refers to the firm's interaction with different collaborators, namely suppliers, customers, competitors, and research 
organizations for the purpose of new product development. Collaborative networks may also exist for the purpose of improved distribution, broader product assortment, increased manufacturing flexibility, and compliance with regulation among others.

Enhancing firms' accessibility to complementary resources, facilitating the exchange of tacit and explicit knowledge, and reducing the risk of R\&D activities by spreading the associated costs over different channel partners are amongst the main advantages of collaborative innovation networks (Faems et al., 2005). In line with existing literature that defines collaborative innovation networks as the extent to which channel members participate in new product development and innovation processes (Tsai, 2009), we focus on collaborative innovation networks and consider them as a feature of the innovation process (Alexiev et al., 2016; Möller \& Halinen, 2017).

An extensive body of literature has investigated the impact of different types of collaborative innovation networks on new product performance (Clauss \& Kesting, 2017; Faems et al., 2005; Heirati et al., 2016). However, there remain inconsistencies in the findings. For example, whereas some researchers (Luzzini et al., 2015; Najafi-Tavani et al., 2014; Nieto \& Santamaría, 2007) have shown a positive impact of collaborative innovation networks on new product performance, others have found insignificant or even negative effects (Belderbos et al., 2004; Freel, 2003).

These inconsistencies can be explained from different perspectives. From an empirical standpoint, they can be attributed to the different settings of the research. For example, Luzzini et al. (2015) conducted their research on the path of innovation and provided support for their hypotheses across 10 different countries in Europe and North America. In contrast, Tsai (2009) failed to find support for the direct effect of collaborative networks on product innovation performance in the context of traditional Taiwanese manufacturing firms. Similarly, Freel (2003) examined the association between collaborative relationships and both product and 
process innovativeness in the context of 'Northern British' SMEs. He found that while firms with greater spatial reach of innovation-related networks are more likely to introduce novel product or process innovations, a considerable variety of such associations exist across different sectors and innovation types.

From a theoretical perspective, these inconsistencies can be attributed to either a lack of sufficient attention being paid to contingency factors in the association between collaborative innovation networks and new product performance, and/or the mechanism of such effects not being conceptualized accurately. Examination of these mechanisms/contingency factors are crucial, since they enhance our understanding of how and under what conditions collaborative innovation networks enhance new product performance.

The main objective of this study is therefore to cast more light on the association between collaborative innovation networks (as defined in this paper) and new product performance. In doing so, we introduce product and process innovation capabilities as the mechanisms through which collaborative innovation networks lead to enhancing new product performance and examine whether this association between collaborative innovation networks and product and process innovation capabilities are contingent on the level of absorptive capacity.

The theoretical grounding for our arguments is the Resource Based View (RBV) of the firm and organizational learning theory. Based on the RBV, we argue that only firms with certain internal capabilities (i.e. product innovation capability, process innovation capability, and learning capability) can achieve superior performance (Barney, 1991; Hamel \& Prahalad, 1994; Mitrega et al., 2017). From this perspective, firms are seen as "bundles of resources and may take the strategic decision to engage in a co-operative agreement that permits them to articulate different sets of complementary resources in their pursuit of sustainable competitive advantage" (Mention, 2011, p. 45). Innovation capability (comprising product innovation capability and process innovation capability) is recognized as one of the most important 
internal resources that can result in superior firm performance (Perna et al., 2015). Without such internal capabilities, a firm's knowledge acquisition through collaborative innovation networks (as a resource) has little value, particularly in terms of new product success, since it is unable to efficiently employ these resources.

However, our main argument in this study is that while expanding on collaborative innovation network is necessary, it is not a sufficient condition for enhancing innovation capability and new product development success. Instead, we theorize the need for organizational learning capability to act as a complement i.e. collaborative innovation networks improve firms' innovation capability only in the presence of organizational learning capability. Previous studies have suggested learning as an essential antecedent of firms' innovation ability (Alegre \& Chiva, 2008; Nabil Amara et al., 2008; Chen et al., 2009). Recent theories of organizational learning have highlighted the concept of absorptive capacity (AC) to clarify the learning process in organizations (Tu et al., 2006; Winkelbach \& Walter, 2015). However, existing literature (Wu, 2014) has so far focused on the impact of collaborative innovation networks on innovation capability without paying sufficient attention to the contingent effects of absorptive capacity of the firm.

Thus, the main contributions of this research are to first examine the role of product and process innovation capabilities as two distinct mechanisms through which collaborative innovation networks impact new product performance, and secondly, to examine whether the relationship between collaborative innovation networks and product and process innovation capabilities is contingent on the firm's level of absorptive capacity.

\section{Theoretical background and research hypotheses}




\subsection{Collaborative innovation networks, innovation capability and new product performance}

Research on network management has evolved over the last two decades. Several approaches exist forthe study of business networks (for a complete review on different streams of research in the study of business networks please see Möller and Halinen (2017)). Möller and Svahn (2003) introduced the strategic net perspective, a concept that refers to firms' attempts to form strategic networks with a few focal actors in order to pursue mutual strategic goals beyond their individual resources. Ford et al. (2002) introduced the concept of network pictures, which represent “an organizational actor's subjectively perceived network" (Ramos et al., 2012, p. 952). The network picture approach has been the focus of research for the study of networks in recent years (e.g. Abrahamsen et al., 2016; Ramos et al., 2012).

Innovation networks is yet another stream of research in network management studies that focuses mainly on collaboration with different actors aiming at innovation. To examine how firms' external actors (e.g. suppliers, customers, competitors, and research organizations) impact their innovation capability or new product performance, researchers focus on the role that relationships and networks play in developing innovative processes and products. According to the industrial network approach, firms are embedded in a complex web of interconnected ties through which they can access the resources that are needed for sustaining the business (or in our case, successfully developing new products). Based on this perspective, firms purposefully develop networking capabilities (Mitrega et al., 2017) (i.e. initiating, managing, and/or terminating business relationships) to guide the relational and network properties that they are embedded in to leverage their competitive advantage through achieving greater innovativeness (Freytag \& Young, 2014). From this perspective, firms' accessibility to new external sources of knowledge and their innovation ability depends on their embedded network. 
Innovation networks have increasingly attracted both researchers' and practitioners' attention as an appropriate solution to increased knowledge intensity and the ever-increasing cost of $R \& D$ that together with globalization of production have made it progressively difficult for an individual company to stay creative and be innovative in the long run. Science-driven networks, design networks, platform constructing networks, new product networks, and commercialization networks are just few examples of collaborative innovation networks that are formed to facilitate the new product development process.

To study innovation networks, some researchers follow the social network analysis approach, which looks at different network characteristics (e.g. power, centrality, size, and tie strength), structural properties (e.g. structural holes and network density), and networking ability ( Afuah, 2013; Demirkan \& Demirkan, 2012; Goerzen, 2007; La Rocca et al., 2016; Naudé et al., 2014; Phelps, 2010). According to the network view, these factors drive firms' innovative capability mainly through enhancing their access to novel knowledge/ideas, minimizing knowledge redundancy, enhancing joint problem solving, and alleviating uncertainties (Ahuja, 2000; Chung et al., 2016).

Instead of focusing on structural properties of the network, other scholars have focused on the level of collaboration with external actors (such as suppliers, customers, competitors, and research organizations) as a driver of innovation capability (e.g. Alexiev et al., 2016; Clauss \& Kesting, 2017; Heirati et al., 2016; Luzzini et al., 2015; Tsai, 2009). Our research adopts the latter approach to investigate whether and under what conditions the interaction with different collaborators enhances new product performance in terms of product success in meeting sales goals, market share goals, return on investment and customer satisfaction. This approach can best serve the purpose of this research, given that we are not focusing on the structural properties of the embedded network of a focal firm and how that may help in driving innovation 
capability, but instead we endeavor to explain how collaboration with different external actors can help a firm in developing new products.

Our arguments are grounded in the Resource Based View of the firm and organizational learning theory. The RBV suggests that accessing strategic resources is the main driver of companies' competitive advantage (Barney, 1991). In line with this perspective, we argue that collaborating with external actors to develop new products or processes enhances firms' accessibility to scarce resources that they may lack internally. One of these critical resources is knowledge (Grant, 1996) which is defined as "information that is relevant, actionable, and based at least partially on experience" (OECD, 2005, p. 113). Knowledge can be explicit or tacit (Camisón \& Villar-López, 2014; Nonaka et al., 1996); while the former is codified, the latter is rooted in experiences, procedures, emotions, and skills (Nonaka et al., 2000), and thus extremely difficult, if not impossible, to explain and exchange (Fayard et al., 2012).

Earlier studies increasingly highlight the importance of collaboration with different types of partners (i.e. suppliers, customers, competitors, and universities/research organizations) in enabling firms to develop innovative products particularly through accessing tacit knowledge (Tsai, 2009). The increased complexity of knowledge processes, as a key driver of innovation, encourages companies to investigate and explore fruitful knowledge beyond their own boundaries, in order to strengthen their internal capabilities (Becker \& Dietz, 2004; De Faria et al., 2010). In other words, since essential resources and capabilities for innovation are not always embedded inside the firms, collaboration can offer a means for reducing this limitation (Das \& Teng, 2000; Nieto \& Santamaría, 2007).

Building on earlier studies on collaborative innovation networks (Liao et al., 2011), we argue that such arrangements facilitate the intrafirm exchange of resources, particularly tacit knowledge (as the exchange of such knowledge requires direct personal interactions) (Ireland \& Webb, 2007; Liao et al., 2011). The main rationale is that through enhancing direct 
interactions, collaboration with external actors increases the mutual trust and the willingness of both parties (i.e. knowledge holder and seeker) to engage in knowledge exchange activities (Liao et al., 2011). Collaborative innovation networks can thereby create competitive advantage through increasing the firm's accessibility to and facilitating the intrafirm exchange of strategic resources (e.g. tacit knowledge) (Fayard et al., 2012).

The central criticism of RBV is that it may not be sufficient to explain the variations in firms' performance. The reason for this is that while possessing strategic resources is important, a firm should have the internal capabilities to be able to benefit from such resources (Newbert, 2007). Capability refers to the firm's specific resources, usually non-transferable and embedded in skills and experiences, whose aim is to enhance the efficiency of the firm's other resources (Makadok, 2001). We argue that while collaboration with external actors is important, this does not automatically translate into improved new product performance. Our study therefore focuses on two set of internal capabilities: innovation capability and absorptive capacity.

Innovation capability includes product and process innovation capability and it refers to development of new or significantly changed products and processes (Camisón and VillarLopez 2014). The second organizational capability that this research focuses on is absorptive capacity. According to Tu et al. (2006), absorptive capacity, as one of the main components of organizational learning, assists firms to identify, communicate, and assimilate both externally and internally relevant knowledge. We therefore consider absorptive capacity as a boundary condition that can facilitate firms' ability to use knowledge resources gained through collaboration with external actors. In other words, we investigate whether the relationship between collaborative innovation networks and innovative capability is contingent on the level of absorptive capacity (See Figure 1). 


\subsection{Collaborative innovation networks and innovation capability: the moderating role of absorptive capacity}

Innovation can only take place if companies have a proper set of capabilities to innovate (Laforet, 2011). Innovation is usually explained in terms of changes in what a company introduces to the market (product/service innovation) and the approaches it employs to create and deliver those offerings (process innovation) (Francis \& Bessant, 2005; Liao et al., 2007). Product innovation capability reflects the ability of firms to introduce new products or services in order to satisfy market needs (Damanpour, 1991; Mitrega et al., 2017; Zaefarian et al., 2017), or employing new technologies for commercial use (Lukas \& Ferrell, 2000). By contrast, process innovation reflects introducing new inputs or processes (including materials, task specifications, work and information flow mechanisms, and equipment) to the firm's production operations, which are then employed to manufacture a product (Damanpour, 1991) and which consequently facilitates improving quality and/or saving costs (Johne, 1999; Nasution et al., 2011).

Firms introducing innovation characterized by a higher degree of novelty usually use a wider range of knowledge sources to develop their products (Nabil Amara \& Landry, 2005). As such, firms possessing strong collaboration with different partners are more likely to develop stronger innovation capabilities (De Faria et al., 2010; Mention, 2011), which in turn may enable them to achieve superior outcomes (Calantone et al., 2002). Higher levels of collaborative innovation increases the frequency of direct interactions between a focal firm and its external actors, which can then considerably enhance the intrafirm exchange of strategic resources (such as tacit knowledge) (Ireland \& Webb, 2007). As a result, firms that collaborate with their external actors are in a better position to innovate since such arrangements increase 
their accessibility to the strategic resources required for developing new products and processes.

We argue that while collaboration with market actors can play a key role in firms' innovation capabilities, its ultimate impact may depend on the individual company's level of absorptive capacity. Of the many factors highlighted in the literature as determinants of successful innovation, absorptive capacity (AC) is known to be critical (Najafi-Tavani et al., 2016; Wu, 2014; Zahra \& George, 2002). While AC was originally conceptualized and used to deal primarily with external knowledge (see Cohen \& Levinthal, 1990; Lichtenthaler \& Lichtenthaler, 2009), researchers have since argued that firms should also consider their internal knowledge, to facilitate internal diffusion of new knowledge (e.g. Jones \& Craven, 2001; Tu et al., 2006). We concur with the latter view, which defines absorptive capacity as "the organizational mechanisms that help to identify, communicate, and assimilate relevant external and internal knowledge" (Tu et al., 2006, p. 694).

As discussed earlier, collaborative innovation networks can increase firms' accessibility to the knowledge resources of different actors in the external environment. However, the benefits of forming collaborative innovation networks can only be realized when a firm has a high level of absorptive capacity. In other words, a sufficient degree of absorptive capacity is required for effective learning in a collaborative agreement between firms (Lane et al., 2001; Tsai, 2009). Having strong absorptive capacity enables firms to identify, communicate, and scan/assimilate partners' knowledge resources. It has been argued that absorptive capacity enhances firms' sensitivity towards knowledge resources existing in the external environment (Winkelbach \& Walter, 2015; Zahra \& George, 2002). It also assists firms to utilize (Chen et al., 2009), develop and reconfigure the acquired external knowledge (Eisenhardt \& Martin, 2000). Consequently, when the level of absorptive capacity is high, a company is in a better position 
to scan and utilize the external knowledge (Tzokas et al., 2015) acquired through collaborative innovation networks, thereby increasing innovative capabilities.

Conversely, regardless of the extent and quality of collaborative innovation networks, a company with poor capability to absorb knowledge and technology reduces its ability to learn from partners which can decrease innovation capability (Johnson et al., 2004). A company that is unable to effectively identify external knowledge, has a communication climate hampering knowledge sharing, or does not have adequate knowledge to deal with new ideas, processes, or technologies, may overlook the value of external knowledge and thus becomes less willing or able to learn from its external actors, which can ultimately decrease its innovation capability (Winkelbach \& Walter, 2015). Even if the firm acquires knowledge, a low level of absorptive capacity means that it may not be capable of capitalizing on it. In other words, the firm's ability to effectively utilize newly gained knowledge to develop new products and processes is limited since it is unable to develop and reconfigure such resources. Therefore, we argue that through enhancing firms' learning capabilities, absorptive capacity moderates the association between collaborative innovation networks and the two types of innovation capabilities:

Hla: The positive impact of collaborative innovation networks on product innovation capability is moderated by absorptive capacity.

H1b: The positive impact of collaborative innovation networks on process innovation capability is moderated by absorptive capacity.

\subsection{Innovation Capabilities and New Product Performance}

There is much research on the effectiveness of product and process innovation capabilities and their effect on new product performance (see for example, Mitrega et al., 2017). Although new product development is not always successful, and some literature suggests the success rate to be as low as $25 \%$ (Evanschitzky et al., 2012), the existence of product and process innovation 
capabilities can enhance the success rate of new product development, but in different ways. On one hand, product innovation capability enables firms to effectively transform their resources into innovative offerings that are meaningfully different from other similar offerings in the market, and are better in terms of quality, and so are more attractive to customers (Camisón \& Villar-López, 2014). On the other hand, the process innovation capabilities are mainly associated with the ability of a firm to improve its internal processes such as efficiency and effectiveness of production (Damanpour et al., 2009) that ultimately reduce the cost of production (Damanpour, 2010) and thus enhances the performance of newly developed products.

Therefore, consistent with previous works (e.g. Mitrega et al., 2017, Zaefarian et al., 2017), we propose that product innovation and process innovation capabilities are directly linked to new product performance.

H2a: Product innovation capability has a positive effect on new product performance.

H2b: Process innovation capability has a positive effect on new product performance.

\section{Research methodology}

\subsection{Sample selection and data collection}

We carried out our empirical research through the utilization of a questionnaire-based survey. We collected data from a sample drawn from the Middle East, specifically the Iranian manufacturing industry. The manufacturing industry in the Middle East and Africa is historically associated with sluggish performance. However, in this region manufacturing is currently booming, partly due to the relatively low oil prices, and it is increasingly becoming the key driver of wider economic performance. To move in this direction, the traditional manufacturing industries in this region need to identify and seize improvement opportunities. Innovation capability can therefore help the manufacturing companies to implement the 
process and technological improvements needed for sustainable development of the industry. Iran is representative of many countries in the Middle East (by both stage of development and culture), and as such this population can be extended to other countries.

We prepared the English version of the questionnaire based on an extensive review of the pertinent literature on collaborative innovation networks, absorptive capacity, innovation capability, and new product performance. This was then refined through a consultation process involving academics and research peers. In the next stage, the questionnaire was translated into Farsi and back-translated by two independent professional translators in order to reduce concerns regarding the conceptual equivalence. We also conducted a pilot study of six innovation mangers to further examine the face validity of the measures employed in the study.

Following the recommendation of Hoskisson et al. (2000) for conducting research in emerging economies, the survey was administered through personal interviews. The process was one of randomly selecting 1000 manufacturing firms from the Iranian Ministry of Industry, Mine and Commerce database (www.behinyab.ir). These were individually checked to determine whether or not they were still in operation. A total of 85 were found to have ceased trading, and so 915 potential respondents were contacted by telephone to ask if they were willing to participate in our research. These were typically the vice president, product manager, or director of new product innovation and development. The companies in the sample were asked whether or not they had introduced any new products to the market within the last three years. This was done to ensure that they had recently introduced new products and were therefore appropriate to be considered in our study. Overall a total of 258 firms confirmed that they had introduced at least one product to the market over the previous three years and also that they were willing to participate in the survey. The survey was completed on site through personal appointments with the key informants. We collected a total of 258 responses, giving a response rate of 100 percent of those qualified firms that agreed to participate in our study. 
Non-response bias is a common concern in empirical studies employing surveys. A comparison between the respondent and non-respondent firms showed that there are no significant differences in terms of key firm characteristics, and thus non-response bias is not a cause for concern in this study. The firms responding to the survey covered a good range of different high technology and medium-to- high technology manufacturers which were classified based on the OECD (2003) industry classification. Out of the 258 usable cases, $35 \%$ of firms operate in the chemical industry, $28 \%$ in medical/pharmaceutical, $25 \%$ in electrical and electronics, and $12 \%$ in engineering and machinery equipment. The companies participating in the research had been in business for between 5 and 63 years, and the total number of employees that they employed ranged from 15 to 6500 .

\subsection{Common method bias}

Since we gathered data for both dependent and independent constructs from a single-informant, common method bias (CMB) might be problematic. To reduce concerns regarding $\mathrm{CMB}$, we followed the three-step procedure suggested by Podsakoff et al. (2003): first, we adapted the construct measurements from the pertinent literature through a systematic questionnaire development process resulting in good clarity of the research measurement items. As mentioned earlier, the questionnaire was also refined through a consultation process involving academics and research peers in order to amend vague and unclear expressions and grammatical complexity. Secondly, to ensure that informants could not easily speculate on the relationship among the research constructs, we randomly positioned the items in the questionnaire instead of categorizing them in their predefined variables. Thirdly, the anonymity of participants was explained and assured in both the questionnaire and also through the personal interview to secure the accuracy of responses.

After conducting the survey, confirmatory factor analysis (CFA) was used to evaluate the possibility of CMB by comparing the fit indices between the models with different levels of 
complexity. Common method bias could be problematic in the research when fit indices of a simpler model are similar to a more complex model (Korsgaard \& Roberson, 1995). To test for CMB, two models were developed: in the first model all items were loaded on to one confirmatory factor resulting in $\chi^{2}=4677.86$ and $d f=902$. The second model was a research measurement model with $\chi^{2}=1329.91 ; d f=866$. Since the comparison between two models depicted a significantly different result $\left(\Delta \chi^{2}\right.$ of 3347.95 with $\left.\Delta d f=36, \mathrm{p}<0.001\right)$, we concluded that CMB was not a major concern in this study. We also ran a marker variable test (Lindell \& Whitney, 2001). In doing so, we considered the second smallest positive correlation among the research variables (i.e. 0.002 , the correlation between product innovation capability and firm's size) as an estimate of the marker variable. Using this market variable, the CMB-adjusted correlations were then calculated for each pair of variables, asserting that the adjustment causes no difference to the statistical significance of the correlations. While we cannot fully reject the existence of the common method bias, the explained analyses reduced concerns regarding the CMB.

\subsection{Measures}

The measures utilized in this study were all adapted from previous studies. A seven-point Likert scale was employed to assess the research constructs. A full description of the scales employed and item loadings are presented in Appendix 1. A five-item scale for "new product performance" was adopted from the study of Langerak et al. (2004) and reflects the dimensions of market level, financial output, and customer acceptance and satisfaction measures of new product success.

"Collaborative innovation networks" represents the four types of collaboration with different partners and was measured following the approach of Tsai (2009). We used four single-item scales to measure the level of collaboration with different types of partners, namely suppliers, 
customers, competitors and university/research organizations. We constructed each of these variables by asking the extent to which a firm collaborates with the given partner.

"Product innovation" and "Process innovation" capabilities measures (using a five-item scale and a ten-item scale respectively) were adopted from the study of Camisón and Villar-Lopez (2014). The "Product innovation capability" scale assesses an ability of firms to develop new or significantly improved products. The scale for "process innovation capability" measures the ability of firms to develop new or significantly changed productive and technological processes.

In the research undertaken, absorptive capacity is a second-order construct. We employed the definition and measurements of absorptive capacity (AC) suggested by Tu et al. (2006) which has been widely used to measure AC in previous studies (e.g. Kauppi et al., 2013; Liao et al., 2011; Najafi-Tavani et al., 2014). They defined AC as mechanisms that assist a firm in identifying, communicating, and assimilating knowledge existing in either internal or external environment. In this conceptualization, "the elements of $A C$ are considered to be the firm's existing knowledge base, the effectiveness of systems that scan the environment, and the efficacy of the firm's communication processes" (Tu et al., 2006, p. 694).

Following Tu et al. (2006), we focused on five sub-dimensions of absorptive capacity, namely manager knowledge, worker knowledge, communications network, communications climate, and knowledge scanning. Manager and worker knowledge refer to understanding of the skills, technology and organizational practices possessed by managers and employees respectively. Manager and worker knowledge can be considered as human capital which can be improved by training and experience (Erickson \& Rothberg, 2009). A firm that possesses high levels of manager and worker knowledge is in a better position to absorb and utilize new sources of knowledge and thus it is more capable of developing new knowledge. The communication network refers to the scope and strength of structural relationships while the communications 
climate refers to the atmosphere within the firm that determines "accepted communication behaviour" (Tu et al., 2006, p. 695). A strong communication network not only increases the firm's accessibility to new sources of knowledge but also facilitates the exchange of knowledge, particularly highly tacit knowledge. An open communication climate can enhance the firm's innovation capability through encouraging both teamwork and an open exchange of information (Nordin et al., 2014). Finally, knowledge scanning can be considered as mechanisms that enable firms to identify and attain relevant internal and external knowledge resources, which can lead to higher innovation capabilities (Tu et al., 2006). As for the five dimensions of absorptive capacity, "Worker knowledge" and "manager knowledge" were measured by employing four items for each. "Communications climate" and "communications network" were measured by employing six and five items scales respectively. "Knowledge scanning" was measured by adopting a seven-item scale.

\section{Analysis}

\subsection{Reliability, validity, and descriptive statistics}

Before estimating the overall model, we first examined our measurement model using confirmatory factor analysis (CFA). This procedure enabled us to purify the measurements and improve the fit indices of the research model. We performed our CFA analysis by employing AMOS 22.0. The fit indices showed the model to fit the data adequately, with $\chi^{2}=1329.91 ; d f$ $=866 ; \mathrm{IFI}=0.932 ; \mathrm{TLI}=0.925 ; \mathrm{CFI}=0.932 ;$ and $\mathrm{RMSEA}=0.046$. Table 1 presents the summary statistics of our measurement analysis consisting of the means, standard deviations, the loadings of each item, average variances extracted (AVE), and composite reliabilities (CRs) of the constructs employed in the study. As can be seen in this table, all item loadings are greater than 0.6 and significant at the 0.01 level representing convergent validity (Bagozzi et al., 1991). We also calculated composite reliabilities and the AVEs for each construct. All CRs are above the minimum threshold of 0.7 and AVEs are all above the accepted level of 0.5 . 
Table 2 presents the comparison between the square root of the AVEs and the inter-construct correlation estimates. Since the square root of the AVEs for all constructs are greater than the related construct correlations, discriminant validity is achieved (Fornell \& Larcker, 1981).

Insert Tables 1 and 2 about here

\subsubsection{Second-order factor (absorptive capacity)}

As discussed earlier, in the research model, absorptive capacity is a higher-order construct composed of worker knowledge, manager knowledge, communications network, communications climate, and knowledge scanning. Table 3 presents the loadings, AVE and fit indices. The loadings from first-order factors to the second-order factor range from 0.62 to 0.80 , and so are within the acceptable range and significant at $\mathrm{P}<0.01$. While the ratio of $\chi^{2}$ to $d f$ is 1.70, IFI is 0.958, TLI is 0.952, CFI is 0.958 and RMSEA is 0.052 , the AVE for absorptive capacity is 0.525 showing that the model fits the data well enough. Given these results, the second-order factor model was employed to represent the absorptive capacity construct.

Insert Table 3 about here

\subsection{Results}

To examine the research hypotheses, we estimated two structural models in AMOS 22.0 using the maximum likelihood method. While in model 1, we estimated the baseline model to test the main effects, moderating effects were examined in model 2 by adding the interaction term (collaborative innovation networks $\times$ absorptive capacity) to the baseline model.

Model 1 contains collaborative innovation networks, absorptive capacity, and product and process innovation capabilities, as well as the control variables (i.e. firms' size and age). The natural logarithm value was given to each control variable instead of the original value to deal with the problem of skewness. The result of the baseline structural model indicated that the 
model fitted the data sufficiently well, with $\chi^{2}=1491.20 ; d f=968 ;$ IFI $=0.924$; TLI $=0.918$; $\mathrm{CFI}=0.923$; and RMSEA $=0.046$. Table 4 presents the standardized path coefficient (SPC) for the relationships in the research model. As shown, collaborative innovation networks alone have no direct impact on either product innovation capability $(S P C=0.012, \mathrm{p}>0.5$, t-value $=$ $0.143)$ or process innovation capability $(S P C=-0.011, \mathrm{p}>0.5$, t-value $=-0.138)$.

We then created and included in the structural model (model 2) the interaction term between absorptive capacity (AC) and collaborative innovation networks (CIN) following the procedure suggested by Ping (1995). Note that we first mean-centered item values for absorptive capacity and collaborative innovation networks constructs before creating the product term $\mathrm{CIN} \times \mathrm{AC}$ to avoid multi-collinearity problem. As shown in table 4, the path from the interaction term $\mathrm{CIN} \times \mathrm{AC}$ to the product innovation capability is positive and significant $(S P C=0.327, \mathrm{p}<$ 0.01 , t-value $=5.024)$, supporting $\mathrm{H}_{1 \mathrm{a}}$. The path from $\mathrm{CIN} \times \mathrm{AC}$ to process innovation capability is also positive and significant $(S P C=0.322, \mathrm{p}<0.01$, t-value $=5.114)$, hence $\mathrm{H}_{1 \mathrm{~b}}$ is supported as well.

Product and process innovation capabilities also have positive and significant effect on new product performance (for product innovation capability: $S P C=0.367, \mathrm{p}<0.01$ in model 1 and $0.362, \mathrm{p}<0.01$ in model 2; and for process innovation capability: $S P C=0.260, \mathrm{p}<0.05$ in model 1 and $0.265, \mathrm{p}<0.05$ in model 2); providing support to both $\mathrm{H}_{2 \mathrm{a}}$ and $\mathrm{H}_{2 \mathrm{~b}}$. Absorptive capacity also has a positive and significant effect on both product innovation capability (SPC $=0.435, \mathrm{p}<0.01$ in model 1 and $0.388, \mathrm{p}<0.01$ in model 2 ) and process innovation capability $(S P C=0.515, \mathrm{p}<0.01$ in model 1 and $0.466, \mathrm{p}<0.01$ in model 2$)$.

Overall, model 1 explained a total of $20 \%$ of the variance in product innovation capability, $26 \%$ of the variance in process innovation capability, and $35.5 \%$ of the variance in new product performance. Model 2 explained a total of $29.8 \%$ of the variance in product innovation capability and $35.3 \%$ of the variance in process innovation capability. In other words, by 
adding the interaction terms to the baseline model, our analysis revealed significant incremental changes in total variances explained in both product and process innovation capabilities $\left(\Delta \mathrm{R}^{2}=\right.$ $9.8 \%$; and $9.3 \%$ respectively), indicating the presence of moderating effects. To facilitate interpretation of the moderating effects, the interactions are graphically presented in Figure 2. It should be noted that our control variables do not result in significant associations with new product performance, product innovation capability, and process innovation capability in both models.

Insert Table 4 and Figure 2 about here

\section{Discussion and Conclusion}

This study provides an important contribution to the marketing literature, shedding light on whether and under what conditions collaborative innovation networks enhance new product performance in technology-intensive firms. Our analysis indicates that collaboration with external actors per se does not guarantee an increase in innovation capabilities of the firm. Indeed, collaborative innovation networks enhance innovation capabilities only in the presence of absorptive capacity. In other words, the extent to which collaboration with external actors facilitates innovation capability depends on the level of absorptive capacity. That is, the effect of collaborative innovation networks on both product and process innovation capabilities increases as the level of absorptive capacity escalates. Product and process innovation capabilities are also important predictors of new product performance. Our findings have a number of important theoretical and managerial implications for researchers and practitioners.

\subsection{Theoretical implications}

Our research contributes to the extant literature by explaining the link between collaborative innovation networks and firms' new product performance. Existing literature makes opposing 
predictions regarding the consequences of collaboration with external actors, with either significant (Luzzini et al., 2015; Najafi-Tavani et al., 2014) or insignificant (Belderbos et al., 2004) influence on new product performance. The lack of investigation of contingency effects may explain such mixed results. Unlike past studies (Griffith \& Lee, 2016; Heirati et al., 2016; Luzzini et al., 2015), our research challenges the role of collaborative innovation networks as the key driver of new product performance, and proposes innovation capability and absorptive capacity as necessary internal capabilities that enable firms to benefit from collaborative innovation networks.

Our results indicate that although product and process innovation capabilities have a positive influence on new product performance, collaborative innovation networks per se do not have a direct effect on either product or process innovation capabilities. This research thus contributes to the industrial marketing literature by showing that a resource based view of the firm is not enough to explain the variance in firms' innovation capabilities. Our findings however indicate that the path from collaborative innovation networks to both product and process innovation capability becomes significant in the presence of absorptive capacity. We found that collaborative innovation networks can enhance the firm's ability to innovate only when its level of absorptive capacity is high. This result is in line with an organizational learning perspective which focuses on absorptive capacity as the main determinant of firms' competitive advantages (Tzokas et al., 2015; Winkelbach \& Walter, 2015). An implication of this finding is that a firm should have absorptive capacity to be able to benefit from strategic resources that are available through collaborative innovation networks. In other words, a company's attempts to develop collaborative innovation networks can be considered as a waste of resources when it lacks the internal capabilities to capitalize on external resources.

Collaborating with external partners is an effective mechanism for firms to identify and access the knowledge and information resources that exist in their partners (e.g. Luzzini et al., 2015; 
Najafi-Tavani et al., 2013; Winkelbach \& Walter, 2015). Such collaborative innovation networks are particularly important in Iran given the international sanctions imposed over the last few decades that have forced local firms to rely more on their local actors to gain resources that they lack internally (seeZaefarian et al., 2017; Zaefarian et al., 2016). However, to be able to efficiently utilize available knowledge resources, a firm should have high levels of absorptive capacity (Erickson \& Rothberg, 2009). When the level of absorptive capacity is high, a firm is in a better position to not only be aware of new knowledge and opportunities, but also to assimilate, utilize, and reconfigure available external knowledge (Chen et al., 2009; Eisenhardt \& Martin, 2000; Winkelbach \& Walter, 2015). Conversely, a low level of absorptive capacity limits the firm's ability to effectively capitalize on the acquired knowledge which can then lead to lower levels of innovation capability. This finding enriches the existing literature by establishing theoretical integration of the organizational learning and resources based perspectives that offer insights into when firms can rely on collaborative innovation networks to increase their innovation capability.

As an additional ad-hoc test, we further examined the separate impacts of collaboration with each type of partner (i.e. suppliers, customers, competitors, and universities) on firms' innovation capability. Our results indicate that collaboration with only some of these external actors is fruitful in terms of innovation capability when the level of firms' absorptive capacity is considered. We discuss these findings below for each type of collaborator separately.

Collaboration with Suppliers: It has been argued that collaboration with suppliers enables companies to use their organizational boundaries to generate competitive advantage (Hallikas et al., 2002). The results of earlier studies indicate that collaboration with suppliers can enhance the level of direct interaction and thus trust between a firm and its supplier (Liao et al., 2011) which in turn facilitates the intrafirm knowledge exchanges (Luzzini et al., 2015; Thomas, 2013). Our results are in line with these studies, since they show that collaboration with 
suppliers can help firms to develop new processes. However, this association is significant only when a firm has sufficient levels of absorptive capacity $(\mathrm{SPC}=0.17$, $\mathrm{t}$-value $=2.20, \mathrm{p}<0.05)$. Our analysis indicates that collaboration with suppliers does not influence firms' capability to develop new products $(\mathrm{SPC}=0.03, \mathrm{t}$-value $=0.41, \mathrm{p}>0.05)$

The underlying reason for this finding may be attributed partly to the high level of uncertainty in the Iranian market resulting from international sanctions. In such an environment, companies may become reluctant to share sensitive information and knowledge regarding their new products, an attitude which can then impact the effectiveness of intrafirm collaborations. Another explanation for this finding could be linked to the context of the study. The manufacturing sector in Middle-East countries such as Iran still operate mainly on a traditional basis despite recent growth. In particular, the economic sanctions in Iran over the last few decades has significantly limited the access of firms to new technologies, and for this reason the technology being used in the manufacturing sector is relatively old. Furthermore, sanctions have limited the economic power of the country and restricted imports of new products. Taken together, these conditions have increased levels of customer demand for existing products that industry struggles to meet. As a consequence, manufacturing firms are rarely obliged to focus on customer needs in the design stage of their new product development.

Collaboration with Customers: The results of existing studies show that collaboration with customers enables firms to identify customers' unsatisfied needs, thereby enhancing firms' ability to offer superior products to customers (Carbonell et al., 2009; Hoyer et al., 2010). However, our study does not corroborate this assertion for the impact of the interaction between customer collaboration and absorptive capacity on product innovation capability $(\mathrm{SPC}=0.01$, t-value $=0.06, \mathrm{p}>0.05)$ and process innovation capability $(\mathrm{SPC}=0.02, \mathrm{t}$-value $=0.29, \mathrm{p}>$ $0.05)$. 
A consideration of the environmental turbulence and the uncertainty resulting from international sanctions may explain this finding. It has been argued that in a turbulent environment like the economy of Iran over the last few decades, a firm's main goal is to fight for survival (Heirati et al., 2016). Therefore, managers might tend to have short-term objectives of achieving immediate returns, and for this reason may launch products more quickly or with less feedback from customers than in a more stable business environment. In addition, firms can benefit from and leverage the fact that customers are faced with limited options available to them in such economic conditions. Firms might therefore deliberately pay less attention to detailed customer needs in order to reduce costs and speed up the launch process. Companies may not spend sufficient time interacting with their customers and learning about their needs, and as a consequence companies then increase the risk of a misfit between product and customers' need, and diminish the benefits of collaboration with customers (Heirati et al., 2016).

Collaboration with Competitors: Our analysis demonstrates that while collaboration with competitors can improve firms' ability to develop new products (when the level of absorptive capacity is high) $(\mathrm{SPC}=0.25, \mathrm{t}$-value $=3.44, \mathrm{p}<0.01)$, they have no impact on firms' ability to develop new processes $(\mathrm{SPC}=0.08, \mathrm{t}$-value $=1.15, \mathrm{p}>0.05)$. Cooperation with competitors can be considered as "a market imperfection hampering competitive dynamics and its resulting benefits" which not only diminishes the negative effects of competition, but can also improve information sharing, which results in firms' enhanced product innovation capabilities $(\mathrm{Wu}$, 2014 , p. 200). However, due to the presence of competition, too much cooperation may expose firms to the risk of opportunism and loss of competitive advantage. Firms may thus become less willing to share sensitive information regarding their technologies and production processes, which can then decrease the positive impact of collaboration with competitors on process innovation capabilities (Gnyawali \& Park, 2011). Moreover, firms are pushed to 
improve their product innovation capabilities when they are faced with strong competition. One explanation for developing collaborative relationships with competitors therefore is to learn from each other. Such collaboration can further help firms in sustaining their marketshare. Collaboration with Research Organizations: According to our findings, universities and research organizations are the only external actors that can significantly enhance both firms' product and process innovation capabilities in the presence of high level of absorptive capacity $(\mathrm{SPC}=0.15, \mathrm{t}$-value $=2.11, \mathrm{p}<0.05$ and $\mathrm{SPC}=0.15, \mathrm{t}$-value $=2.21, \mathrm{p}<0.05$ for product and process innovation capability respectively). This is in line with the results of earlier studies that have considered research institutes and universities as knowledge resources associated with low risks that are useful for long-term strategic research (Brettel \& Cleven, 2011), which can improve firms' innovation performance significantly (Miotti \& Sachwald, 2003). In fact, collaboration between firms and research institutes is argued to be a key antecedent of innovation capability (Tijssen, 2002), while the costs incurred from this kind of collaboration are probably lower than those involving collaboration with other types of external partners (Tether, 2002).

\subsection{Managerial implications}

Our study suggests a number of very important implications for managers of technologyintensive firms. One of the most important implications is that if they intend to maximize their ability to innovate, such firms need to access strategic resources such as the technical knowledge existing in the market. Technical knowledge is, however, often tacit and complex and thus acquiring it can be costly and time consuming (Grant, 1996). Managers can only acquire the internal technical knowledge that they lack through collaboration with their partners and universities. Collaboration increases the level of direct interactions between a focal firm and external actors which can then facilitate the exchange of technical knowledge. 
According to our results, while it is important to collaborate with external actors, managers should also focus on enhancing their internal capabilities such as absorptive capacity. Absorptive capacity enables firms to capitalize on acquired knowledge. Firms with high levels of absorptive capacity are more capable of not only identifying new opportunities but also utilizing the acquired knowledge to improve or develop new products and processes. In the absence of absorptive capacity, the firm is unable to capitalize on the external knowledge available through collaborative innovation networks, which can then limit its ability to innovate. Therefore, to be able to effectively develop new product and processes, managers should simultaneously develop collaboration with external actors and improve their absorptive capacity.

Moreover, our study demonstrates that collaborative innovation networks alone cannot enhance the success of newly developed products. They can, however, assist firms to improve their new product performance through enabling them to develop new products and processes. The implications for the practicing manager in technology intensive industries are clear. Managers cannot afford to spend time and effort only on developing their collaborative innovation networks with suppliers, customers, competitors, and universities and research institutes. Attention also has to be paid to developing both product and process innovation capabilities within the company in the search for better product performance.

Regarding the separate impacts of collaboration with suppliers, universities, competitors, and customers, we find that none of them are capable of influencing innovation capability when the level of absorptive capacity is low. However, when the level of absorptive capacity is high, involving suppliers and competitors in innovation activities can assist firms to improve their process and product innovation capabilities respectively. Managers should also enhance the extent of their collaboration with universities as these research institutions can considerably increase both product and process innovation capabilities. 


\subsection{Limitations and Directions for Further Research}

In common with other studies, there are some methodological and theoretical limitations to this study, which should be noted to provide directions for future research. First, this study only investigated the moderating role of absorptive capacity on the association between collaborative innovation networks and the innovation capability of a firm. Other potential managerially meaningful moderators can be considered in future research. For example, future research can examine whether a firm's learning orientation may influence the relationship between collaborative innovation networks and new product performance. Similarly, it has been argued that the power and nature of boundaries within and around firms can increase their ability to learn from their external environment through impacting intrafirm knowledge exchanges (Easterby-Smith et al., 2008). Future studies can therefore focus on whether the collaborative innovation networks - innovation capability relationship is contingent on the level of power and boundary conditions of a firm.

Secondly, we have only examined the role of innovation capabilities as a mechanism to explain the relationship between collaborative innovation networks and new product performance. From the lens of dynamic capability theory (see Teece et al., 1997), we know that different types of capabilities complement each other to lead to better company performance. Hence, future studies can consider other complementary capability combinations such as the interaction of marketing and innovation capabilities, and explore whether they can be used to explain the link between collaborative innovation networks and new product performance.

Thirdly, to measure collaborative innovation networks, following Tsai (2009), we asked managers to specify the extent to which they collaborated with their suppliers, customers, competitors and university/research institutes within their product development and innovation process. While this approach enabled us to provide a more comprehensive overview of collaboration with various types of external actors, it did not include other important 
dimensions of collaboration such as the frequency and nature of collaboration. Studies can operationalize collaborative innovation networks by including these dimensions. Fourthly, our study sheds light on the condition under which collaborative innovation networks enhance new product performance. Future studies can investigate how and under what conditions such collaborations can impact other organizational outcomes such as number of patents, new product introductions, and speed to market.

Finally, it has been shown that network characteristics such as relational ties facilitate collaborative innovation networks through promoting trust and easing the exchange of knowledge between channel partners (Powell et al., 1996). Future studies can thus investigate whether the relationship between collaborative innovation networks and innovative capabilities is contingent upon network characteristics. 


\section{References}

Abrahamsen, M. H., Henneberg, S. C., Huemer, L., \& Naudé, P. (2016). Network picturing: An action research study of strategizing in business networks. Industrial Marketing Management, 59, 107-119.

Afuah, A. (2013). Are Network Effects Really All About Size? The Role of Structure and Conduct. Strategic Management Journal, 34(3), 257-273.

Ahuja, G. (2000). Collaboration Networks, Structural Holes, and Innovation: A Longitudinal Study. Administrative Science Quarterly, 45(3), 425-455.

Alegre, J., \& Chiva, R. (2008). Assessing the impact of organizational learning capability on product innovation performance: An empirical test. Technovation, 28(6), 315-326.

Alexiev, S. A., Volberda, W. H., \& Van den Bosch, A. J. F. (2016). Interorganizational Collaboration and Firm Innovativeness: Unpacking The Role Of The Organizational Environment. Journal of Business Research, 69(2), 974-984.

Amara, N., \& Landry, R. (2005). Sources of information as determinants of novelty of innovation in manufacturing firms: evidence from the 1999 statistics Canada innovation survey. Technovation 25(3), 245-259.

Amara, N., Landry, R. j., Becheikh, N., \& Ouimet, M. (2008). Learning and novelty of innovation in established manufacturing SMEs. Technovation, 28, 450-463.

Bagozzi, P. R., Yi, Y., \& Phillips, W. L. (1991). Assessing Construct Validity in Organizational Research. Administrative Science Quarterly, 36(3), 421-458.

Barney, B. J. (1991). Firm Resources and Sustained Competitive Advantage. Journal of Management, 17(1), 99-120.

Becker, W., \& Dietz, J. (2004). R\&D Cooperation and Innovation Activities of Firms Evidence for the German Manufacturing Industry. Research Policy, 33(2), 209-223.

Belderbos, R., Carree, M., \& Lokshin, B. (2004). Cooperative R\&D and Firm Performance. Research Policy, 33(10), 1477-1492. 
Brettel, M., \& Cleven, N. J. (2011). Innovation culture, collaboration with external partners and NPD performance. Creativity and Innovation Management 20(4), 253-272.

Calantone, R. J., Cavusgil, S. T., \& Zhao, Y. (2002). Learning Orientation, Firm Innovation Capability, and Firm Performance. Industrial Marketing Management, 31(6), 515-524.

Camison, C., \& Villar-Lopez, A. (2014). Organizational innovation as an enabler of technological innovation capabilities and firm performance. Journal of Business Research, 67(1), 2891- 2902.

Camisón, C., \& Villar-López, A. (2014). Organizational Innovation as an Enabler of Technological Innovation Capabilities and Firm Performance. Journal of Business Research, 67(1), 2891-2902.

Carbonell, P., Rodríguez-Escudero, A. I., \& Pujari, D. (2009). Customer Involvement in New Service Development: An Examination of Antecedents and Outcomes. Journal of Product Innovation Management, 26(5), 536-550.

Chen, Y.-S., Lin, M.-J. J., \& Chang, C.-H. (2009). The Positive Effects of Relationship Learning and Absorptive Capacity on Innovation Performance and Competitive Advantage in Industrial Markets. Industrial Marketing Management, 38(2), 152-158.

Chung, H. F. L., Wang, C. L., Huang, P.-h., \& Yang, Z. (2016). Organizational Capabilities and Business Performance: When and How Does the Dark Side of Managerial Ties Matter? Industrial Marketing Management, 55, 70-82.

Clauss, T., \& Kesting, T. (2017). How Businesses Should Govern Knowledge-Intensive Collaborations with Universities: An Empirical Investigation of University Professors. Industrial Marketing Management, 62, 185-198.

Cohen, W. M., \& Levinthal, D. A. (1990). Absorptive Capacity: A New Perspective on Learning and Innovation. Administrative Science Quarterly, 35(1), 128-152. 
Damanpour, F. (1991). Organizational Innovation: A Meta-Analysis of Effects of Determinants and Moderators. Academy of Management Journal, 34(3), 555-590.

Damanpour, F. (2010). An Integration of Research Findings of Effects of Firm Size and Market Competition on Product and Process Innovations. British Journal of Management, 21(4), 996-1010.

Damanpour, F., Walker, M. R., \& Avellaneda, N. C. (2009). Combinative Effects of Innovation Types and Organizational Performance: A Longitudinal Study of Service Organizations. Journal of Management Studies, 46(4), 650-675.

Das, T. K., \& Teng, B.-S. (2000). A Resource-Based Theory of Strategic Alliances. Journal of Management, 26(1), 31-61.

De Faria, P., Lima, F., \& Santos, R. (2010). Cooperation in innovation activities: The importance of partners. Research Policy, 39(8), 1082-1092.

Demirkan, I., \& Demirkan, S. (2012). Network Characteristics and Patenting in Biotechnology, 1990-2006. Journal of Management, 38(6), 1892-1927.

Easterby-Smith, M., Graça, M., Antonacopoulou, E., \& Ferdinand, J. (2008). Absorptive Capacity: A Process Perspective. Management Learning, 39(5), 483-501.

Eisenhardt, K. M., \& Martin, J. A. (2000). Dynamic Capabilities: What are They? Strategic Management Journal, 21(10-11), 1105-1121.

Erickson, G. S., \& Rothberg, N. H. (2009). Intellectual Capital in Business-to-Business Markets. Industrial Marketing Management, 38(2), 159-165.

Evanschitzky, H., Eisend, M., Calantone, J. R., \& Jiang, Y. (2012). Success Factors of Product Innovation: An Updated Meta-Analysis. Journal of Product Innovation Management, 29, 21-37. 
Faems, D., Van Looy, B., \& Debackere, K. (2005). Interorganizational Collaboration and Innovation: Toward a Portfolio Approach*. Journal of Product Innovation Management, 22(3), 238-250.

Fayard, D., Lee, S. L., Leitch, A. R., \& Kettinger, J. W. (2012). Effect of Internal Cost Management, Information Systems Integration, and Absorptive Capacity on InterOrganizational Cost Management in Supply Chains. Accounting, Organizations and Society, 37(3), 168-187.

Ford, D., Gadde, L.-E., Håkansson, H., \& Snehota, I. (2002). Managing Networks. Paper presented at the 18th IMP Conference Perth, Australia.

Fornell, C., \& Larcker, F. D. (1981). Evaluating Structural Equation Models with Unobservable Variables and Measurement Error. Journal of Marketing Research, 18(1), 39-50.

Francis, D., \& Bessant, J. (2005). Targeting Innovation and Implications for Capability Development. Technovation, 25(3), 171-183.

Freel, S. M. (2003). Sectoral Patterns of Small Firm Innovation, Networking and Proximity. Research Policy, 32(5), 751-770.

Freytag, P., \& Young, L. (2014). Introduction to Special Issue on innovations and networks: Innovation of, within, through and by networks. Industrial Marketing Management, 43(3), 361-364.

Gnyawali, D. R., \& Park, B.-J. (2011). Co-opetition between Giants: Collaboration with Competitors for Technological Innovation. Research Policy, 40(5), 650-663.

Goerzen, A. (2007). Alliance Networks and Firm Performance: The Impact of Repeated Partnerships. Strategic Management Journal, 28(5), 487-509.

Gonzalez-Zapatero, C., Gonzalez-Benito, J., \& Lannelongue, G. (2016). Antecedents of Functional Integration During New Product Development: The Purchasing-Marketing Link. Industrial Marketing Management, 52, 47-59. 
Grant, R. M. (1996). Toward the Knowledge-Based Theory of the Firm. Strategic Management Journal, 17, 109-122.

Griffith, A. D., \& Lee, S. H. (2016). Cross-country Collaboration of Marketing Personnel within a Multinational: Leveraging Customer Participation for New Product Advantage. Journal of International Marketing, 24(4), 1-19.

Hallikas, J., Virolainen, V.-M., \& Tuominen, M. (2002). Understanding Risk and Uncertainty in Supplier Networks--A Transaction Cost Approach. International Journal of Production Research, 40(15), 3519-3531.

Hamel, G., \& Prahalad, C. K. (1994). Competing for the Future: Breakthrough Strategies for Seizing Control of Your Industry and Creating the Markets for Tomorrow. Cambridge, MA: Harvard Business School Press.

Heirati, N., O'Cass, A., Schoefer, K., \& Siahtiri, V. (2016). Do Professional Service Firms Benefit From Customer and Supplier Collaborations in Competitive, Turbulent Environments? Industrial Marketing Management, 55, 50-58.

Hoskisson, R. E., Lorraine, E., Chung, M. L., \& Wright, M. (2000). Strategy in Emerging Economies Academy of Management Journal, 43(3), 249-267.

Hoyer, D. W., Chandy, R., Dorotic, M., Krafft, M., \& Singh, S. S. (2010). Consumer Cocreation in New Product Development. Journal of Service Research, 13(3), 283-296. Ireland, R. D., \& Webb, W. J. (2007). A Multi-Theoretic Perspective on Trust and Power in Strategic Supply Chains. Journal of Operations Management, 25(2), 482-497.

Johne, A. (1999). Successful Market Innovation. European Journal of Innovation Management, 2(1), 6-11.

Johnson, L. J., Sohi, S. R., \& Grewal, R. (2004). The Role of Relational Knowledge Stores in Interfirm Partnering. Journal of Marketing, 68(3), 21-36. 
Jones, O., \& Craven, M. (2001). Expanding Capabilities in a Mature Manufacturing Firm: Absorptive Capacity and the TCS. International Small Business Journal, 19(3), 39-55. Kauppi, K., Brandon-Jones, A., Ronchi, S., \& van Raaij, M. E. (2013). Tools Without Skills: Exploring the Moderating Effect of Absorptive Capacity on the Relationship between E- Purchasing Tools and Category Performance. International Journal of Operations \& Production Management, 33(7), 828-857.

Korsgaard, M. A., \& Roberson, L. (1995). Procedural Justice in Performance Evaluation: The Role of Instrumental and Non-Instrumental Voice in Performance Appraisal Discussions. Journal of Management, 21(4), 657-669.

La Rocca, A., Moscatelli, P., Perna, A., \& Snehota, I. (2016). Customer Involvement in New Product Development in B2B: The Role of Sales. Industrial Marketing Management, $58,45-57$.

Laforet, S. (2011). A Framework of Organisational Innovation and Outcomes in SMEs. International Journal of Entrepreneurial Behavior \& Research, 17(4), 380-408.

Lane, P. J., Salk, J. E., \& Lyles, M. A. (2001). Absorptive Capacity, Learning, and Performance in International Joint Ventures. Strategic Management Journal, 22(12), 1139-1161.

Langerak, F., Hultink, E. J., \& Robben, H. S. J. (2004). The Impact of Market Orientation, Product Advantage, and Launch Proficiency on New Product Performance and Organizational Performance. Journal of Product Innovation Management, 21(2), 7994.

Liang, B., Kale, S. H., \& Cherian, J. (2014). Is The Future Static or Dynamic? The Role of Culture on Escalation Of Commitment in New Product Development. Industrial Marketing Management, 43(1), 155-163. 
Liao, S.-H., Fei, W.-C., \& Chen, C.-C. (2007). Knowledge sharing, absorptive capacity, and innovation capability: an empirical study of Taiwan's knowledge-intensive industries. Journal of Information Science, 33(3), 340-359.

Liao, Y., Liao, K., Tu, Q., \& Vonderembse, M. (2011). A Mechanism for External Competence Transfer to Improve Manufacturing System Capabilities and Market Performance. International Journal of Production Economics, 132(1), 68-78.

Lichtenthaler, U., \& Lichtenthaler, E. (2009). A Capability-Based Framework for Open Innovation: Complementing Absorptive Capacity. Journal of Management Studies, $46(8), 1315-1338$.

Lindell, K. M., \& Whitney, J. D. (2001). Accounting for Common Method Variance in CrossSectional Research Designs. Journal of Applied Psychology, 86(1), 114-121.

Lukas, A. B., \& Ferrell, O. C. (2000). The Effect of Market Orientation on Product Innovation. [journal article]. Journal of the Academy of Marketing Science, 28(2), 239.

Luzzini, D., Amann, M., Caniato, F., Essig, M., \& Ronchi, S. (2015). The Path of Innovation: Purchasing and Supplier Involvement into New Product Development. Industrial Marketing Management, 47, 109-120.

Makadok, R. (2001). Toward a Synthesis of the Resource-Based and Dynamic-Capability Views of Rent Creation. Strategic Management Journal, 22(5), 387-401.

Menguc, B., \& Auh, S. (2010). Development and Return on Execution of Product Innovation Capabilities: The Role of Organizational Structure. Industrial Marketing Management, $39(5), 820-831$.

Mention, A.-L. (2011). Co-operation and co-opetition as open innovation practices in the service sector: Which influence on innovation novelty? Technovation 31(1), 44-53.

Miotti, L., \& Sachwald, F. (2003). Co-Operative R\&D: Why and with Whom? An Integrated Framework of Analysis. Research Policy, 32(8), 1481-1499. 
Mitrega, M., Forkmann, S., Zaefarian, G., \& Henneberg, C. S. (2017). Networking Capability in Supplier Relationships and Its Impact on Product Innovation and Firm Performance. International Journal of Operations \& Production Management, 37(5), 577-606.

Möller, K., \& Halinen, A. (2017). Managing business and innovation networks-From strategic nets to business fields and ecosystems. Industrial Marketing Management, 67, 5-22.

Möller, K., \& Svahn, S. (2003). Managing strategic nets: A capability perspective. Marketing theory, 3(2), 209-234.

Mu, J., Thomas, E., Peng, G., \& Di Benedetto, A. (2017). Strategic Orientation and New Product Development Performance: The Role of Networking Capability and Networking Ability. Industrial Marketing Management, 64, 187-201.

Najafi-Tavani, S., Sharifi, H., \& Najafi-Tavani, Z. (2016). Market orientation, marketing capability, and new product performance: The moderating role of absorptive capacity. Journal of Business Research, 69(11), 5059-5064.

Najafi-Tavani, S., Sharifi, H., \& S. Ismail, H. (2014). A Study of Contingency Relationships between Supplier Involvement, Absorptive Capacity and Agile Product Innovation. International Journal of Operations \& Production Management, 34(1), 65-92.

Najafi-Tavani, S., Sharifi, H., Soleimanof, S., \& Najmi, M. (2013). An Empirical Study of Firm's Absorptive Capacity Dimensions, Supplier Involvement and New Product Development Performance. [Article]. International Journal of Production Research, 51(11), 3385-3403.

Nasution, H. N., Mavondo, F. T., Matanda, M. J., \& Ndubisi, N. O. (2011). Entrepreneurship: Its Relationship with Market Orientation and Learning Orientation and as Antecedents to Innovation and Customer Value. Industrial Marketing Management, 40(3), 336-345. 
Naudé, P., Zaefarian, G., Tavani, Z. N., Neghabi, S., \& Zaefarian, R. (2014). The influence of network effects on SME performance. Industrial Marketing Management, 43(4), 630641.

Newbert, L. S. (2007). Empirical Research on the Resource-Based View of the Firm: An assessment and Suggestions for Future Research. Strategic Management Journal, $28(2), 121-146$.

Nieto, M. J., \& Santamaría, L. (2007). The Importance of Diverse Collaborative Networks for the Novelty of Product Innovation. Technovation, 27(6-7), 367-377.

Nonaka, I., Takeuchi, H., \& Umemoto, K. (1996). A Theory of Organizational Knowledge Creation. International Journal of Technology Management, 11(7-8), 833-845.

Nonaka, I., Toyama, R., \& Nagata, A. (2000). A Firm as a Knowledge-Creating Entity: A New Perspective on the Theory of the Firm. Industrial and Corporate Change, 9(1), 1-20.

Nordin, S. M., Sivapalan, S., Bhattacharyya, E., Ahmad, H. H. W. F. W., \& Abdullah, A. (2014). Organizational Communication Climate and Conflict Management: Communications Management in an Oil and Gas Company. Procedia - Social and Behavioral Sciences, 109(0), 1046-1058.

OECD. (2003). OECD Science, Technology and Industry Scoreboard. Paris: OECD Publishing.

OECD. (2005). The Measurement of Scientific and Technological Activities Oslo Manual. Guidelines for Collecting and Interpreting Innovation Data (3rd ed.). Paris: OECD EUROSTAT.

Perna, A., Baraldi, E., \& Waluszewski, A. (2015). Is the Value Created Necessarily Associated with Money? On the Connections between an Innovation Process and its Monetary Dimension: The Case of Solibro's Thin-Film Solar Cells. Industrial Marketing Management, 46(0), 108-121. 
Phelps, C. C. (2010). A Longitudinal Study of the Influence of Alliance Network Structure and Composition on Firm Exploratory Innovation. Academy of Management Journal, 53(4), 890-913.

Ping, A. R. (1995). A Parsimonious Estimating Technique for Interaction and Quadratic Latent Variables. Journal of Marketing Research, 32(3), 336-347.

Podsakoff, P. M., MacKenzie, S. B., \& Lee, J. Y. (2003). Common Method Biases in Behavioral Research: A Critical Review of the Literature and Recommended Remedies. Journal of Applied Psychology, 88(5), 879-903.

Powell, W. W., Koput, K. W., \& Smith-Doerr, L. (1996). Interorganizational Collaboration and the Locus of Innovation: Networks of Learning in Biotechnology. Administrative Science Quarterly, 41(1), 116-145.

Ramos, C., Henneberg, S. C., \& Naudé, P. (2012). Understanding network picture complexity: An empirical analysis of contextual factors. Industrial Marketing Management, 41(6), 951-972.

Teece, J. D., Pisano, G., \& Shuen, A. (1997). Dynamic Capabilities and Strategic Management. Strategic Management Journal, 18(7), 509-533.

Tether, B. S. (2002). Who CoOperates for Innovation, and Why: An Empirical Analysis. Research Policy, 31(6), 947-967.

Thomas, E. (2013). Supplier Integration in New Product Development: Computer Mediated Communication, Knowledge Exchange and Buyer Performance. Industrial Marketing Management, 42(6), 890-899.

Tijssen, J. W. R. (2002). Science Dependence of Technologies: Evidence from Inventions and Their Inventors. Research Policy, 31(4), 509-526.

Tsai, K.-H. (2009). Collaborative Networks and Product Innovation Performance: Toward a Contingency Perspective. Research Policy, 38(5), 765-778. 
Tu, Q., Vonderembse, M. A., Ragu-Nathan, T. S., \& Sharkey, T. W. (2006). Absorptive Capacity: Enhancing the Assimilation of Time-Based Manufacturing Practices. Journal of Operations Management, 24(5), 692-710.

Tzokas, N., Kim, Y. A., Akbar, H., \& Al-Dajani, H. (2015). Absorptive Capacity and Performance: The role of Customer Relationship and Technological Capabilities in High-Tech SMEs. Industrial Marketing Management, 47, 134-142.

Winkelbach, A., \& Walter, A. (2015). Complex Technological Knowledge and Value Creation in Science-to-Industry Technology Transfer Projects: The Moderating Effect of Absorptive Capacity. Industrial Marketing Management, 47, 98-108.

Wu, J. (2014). Cooperation with Competitors and Product Innovation: Moderating Effects of Technological Capability and Alliances with Universities. Industrial Marketing Management, 43(2), 199-209.

Zaefarian, G., Forkmann, S., Mitręga, M., \& Henneberg, C. S. (2017). A Capability Perspective on Relationship Ending and Its Impact on Product Innovation Success and Firm Performance. Long Range Planning, 50(2), 184-199.

Zaefarian, G., Najafi-Tavani, Z., Henneberg, S. C., \& Naudé, P. (2016). Do supplier perceptions of buyer fairness lead to supplier sales growth? Industrial Marketing Management, 53, 160-171.

Zahra, S. A., \& George, G. (2002). The Absorptive Capacity: A Review, Reconceptualization, and Extension. Academy of Management Review, 27(2), 185-203.

Zhou, K. Z., \& Li, C. B. (2012). How Knowledge Affects Radical Innovation: Knowledge Base, Market Knowledge Acquisition, and Internal Knowledge Sharing. Strategic Management Journal, 33(9), 1090-1102. 
Figure 1. Conceptual Framework

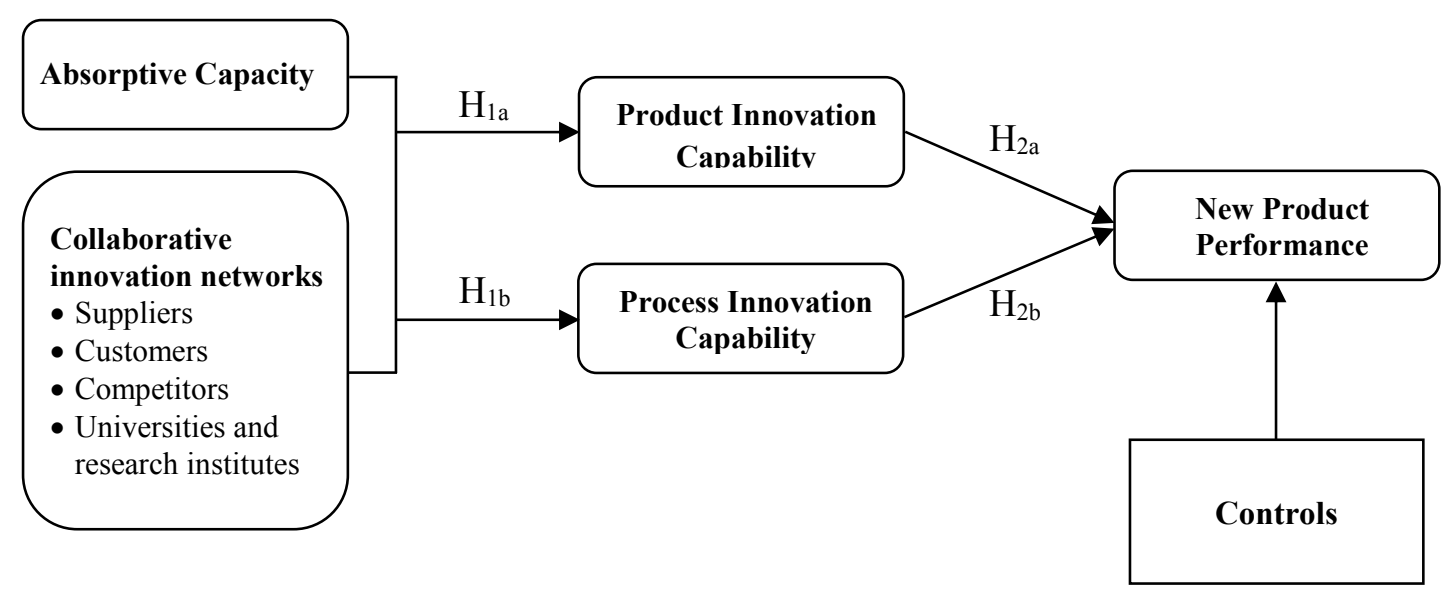


Table 1: Summary statistics of the measurement analysis

\begin{tabular}{lccccc}
\hline Variable & Mean & SD & Item Loading* & AVE & CR \\
\hline New Product Performance & 5.18 & 1.19 & $0.70-0.84$ & 0.594 & 0.853 \\
Collaborative innovation networks & 5.37 & 0.90 & $0.62-0.81$ & 0.561 & 0.835 \\
Worker Knowledge & 4.69 & 1.22 & $0.81-0.89$ & 0.736 & 0.918 \\
Manager Knowledge & 5.27 & 1.23 & $0.79-0.88$ & 0.715 & 0.909 \\
Communications Network & 5.07 & 1.13 & $0.73-0.85$ & 0.650 & 0.881 \\
Communications Climate & 4.79 & 1.30 & $0.72-0.76$ & 0.554 & 0.861 \\
Knowledge Scanning & 5.55 & 1.15 & $0.66-0.82$ & 0.566 & 0.886 \\
Product innovation capability & 5.77 & 1.05 & $0.70-0.80$ & 0.561 & 0.836 \\
Process innovation capability & 5.37 & 1.01 & $0.65-0.83$ & 0.528 & 0.909 \\
Firm's Size & 1.95 & 0.52 & $\mathrm{n} / \mathrm{a}$ & $\mathrm{n} / \mathrm{a}$ & $\mathrm{n} / \mathrm{a}$ \\
Firm's Age & 1.24 & 0.26 & $\mathrm{n} / \mathrm{a}$ & $\mathrm{n} / \mathrm{a}$ & $\mathrm{n} / \mathrm{a}$ \\
\hline
\end{tabular}

Note:* item loadings after deleting values less than 0.6. SD: standard deviation. The natural logarithm value was given to each control variables instead of the original value 
Table 2. Inter-construct correlation estimates and Square Root of the AVEs

\begin{tabular}{|c|c|c|c|c|c|c|c|c|c|c|c|}
\hline & (1) & (2) & (3) & (4) & $(5)$ & (6) & (7) & $(8)$ & (9) & $(10)$ & $(11)$ \\
\hline (1) New product performance & $\underline{0.770}$ & & & & & & & & & & \\
\hline (2) Collaborative network & $0.193^{* *}$ & $\underline{0.749}$ & & & & & & & & & \\
\hline (3) Worker knowledge & 0.109 & $0.413 * *$ & $\underline{0.858}$ & & & & & & & & \\
\hline (4) Manager knowledge & $0.163^{* *}$ & $0.284 * *$ & $0.406^{* *}$ & $\underline{0.845}$ & & & & & & & \\
\hline (5) Communications network & $0.129^{*}$ & $0.383 * *$ & $0.465 * *$ & $0.555^{* *}$ & $\underline{0.806}$ & & & & & & \\
\hline (6) Communications climate & 0.118 & $0.315^{* *}$ & $0.401 * *$ & $0.421 * *$ & $0.415 * *$ & $\underline{0.744}$ & & & & & \\
\hline (7) Knowledge scanning & $0.188^{* *}$ & $0.348 * *$ & $0.443 * *$ & $0.569^{* *}$ & $0.517 * *$ & $0.423 * *$ & $\underline{0.752}$ & & & & \\
\hline (8) Product innovation capability & $0.476^{* *}$ & $0.201 * *$ & $0.221 * *$ & $0.330 * *$ & $0.213 * *$ & $0.239 * *$ & $0.394 * *$ & $\underline{0.749}$ & & & \\
\hline (9) Process innovation capability & $0.451 * *$ & $0.225 * *$ & $0.244 * *$ & $0.377 * *$ & $0.328 * *$ & $0.259 * *$ & $0.392 * *$ & $0.693 * *$ & $\underline{0.727}$ & & \\
\hline (10) Firm Size & 0.043 & 0.026 & 0.047 & 0.059 & $0.158 *$ & -0.003 & 0.001 & 0.002 & 0.030 & $\underline{\text { NA }}$ & \\
\hline (11) Firm Age & -0.067 & 0.024 & -0.040 & -0.007 & 0.016 & 0.033 & 0.016 & -0.067 & -0.026 & $0.309^{* *}$ & $\underline{\text { NA }}$ \\
\hline
\end{tabular}

Note: The bold, underlined figures on the diagonal are the square root of the AVEs.

$$
\begin{aligned}
& *: p<0.05 \\
& * *: p<0.01
\end{aligned}
$$


Table 3: Absorptive Capacity: second order measurement model

First-order construct

Worker knowledge

Manager knowledge

Communications network

Communications climate

Knowledge scanning

$\chi^{2}=383.11, d f=225 ; \mathrm{IFI}=0.96 ; \mathrm{TLI}=0.95 ; \mathrm{CFI}=0.96 ; \mathrm{RMSEA}=0.05 ; \mathrm{AVE}=0.53$
Absorptive capacity

0.63

0.77

0.77

0.62

0.80 
Table 4: Estimation of the Structural Model

\begin{tabular}{|c|c|c|c|}
\hline Structural Model Statistics & $\begin{array}{l}\text { Main effects } \\
\text { (Model 1) }\end{array}$ & \multicolumn{2}{|c|}{$\begin{array}{l}\text { Interaction Effects } \\
\text { (Model 2) }\end{array}$} \\
\hline $\mathrm{X}^{2}$ & 1491.20 & \multicolumn{2}{|c|}{1517.57} \\
\hline d.f. & 968 & \multicolumn{2}{|c|}{1007} \\
\hline CFI & 0.923 & \multicolumn{2}{|l|}{0.925} \\
\hline TLI & 0.918 & \multicolumn{2}{|l|}{0.920} \\
\hline RMSEA & 0.046 & \multicolumn{2}{|l|}{0.044} \\
\hline Path & Path Estimate & \multicolumn{2}{|c|}{ Path Estimate } \\
\hline \multicolumn{4}{|l|}{ predictors } \\
\hline CIN $\rightarrow$ Product Innovation Capability & $0.012(0.143)$ & 0.121 & $(1.383)$ \\
\hline $\mathrm{CIN} \rightarrow$ Process Innovation Capability & $-0.011 \quad(-0.138)$ & 0.095 & $(1.179)$ \\
\hline Product Innovation Capability $\rightarrow$ NPP & $0.367(3.171)$ & 0.362 & $(3.111)$ \\
\hline Process Innovation Capability $\rightarrow$ NPP & $0.260 \quad(2.288)$ & 0.265 & $(2.318)$ \\
\hline AC $\rightarrow$ Product Innovation Capability & $0.435 \quad(4.218)$ & 0.388 & $(3.983)$ \\
\hline AC $\rightarrow$ Process Innovation Capability & $0.515(4.841)$ & 0.466 & $(4.692)$ \\
\hline \multicolumn{4}{|l|}{ Interactions } \\
\hline $\mathrm{CIN} \times \mathrm{AC} \rightarrow$ Product Innovation Capability & & 0.327 & $(5.024)$ \\
\hline $\mathrm{CIN} \times \mathrm{AC} \rightarrow$ Process Innovation Capability & & 0.322 & $(5.114)$ \\
\hline \multicolumn{4}{|l|}{ Controls } \\
\hline Firm's size $\rightarrow$ NPP & $0.053 \quad(0.886)$ & 0.053 & $(0.881)$ \\
\hline Firm's age $\rightarrow$ NPP & $-0.042 \quad(-0.691)$ & -0.042 & $(-0.705)$ \\
\hline Firm's size $\rightarrow$ Product Innovation Capability & $-0.027 \quad(-0.410)$ & -0.009 & $(-0.138)$ \\
\hline Firm's size $\rightarrow$ Process Innovation Capability & $0.009(0.151)$ & 0.029 & $(0.488)$ \\
\hline Firm's age $\rightarrow$ Product Innovation Capability & $-0.072(-1.079)$ & -0.092 & $(-1.444)$ \\
\hline Firm's age $\rightarrow$ Process Innovation Capability & $-0.030 \quad(-0.489)$ & -0.048 & $(-0.812)$ \\
\hline $\boldsymbol{R}^{2}$ (Product Innovation Capability) & 0.200 & 0.298 & \\
\hline $\boldsymbol{R}^{2}$ (Process Innovation Capability) & 0.260 & 0.353 & \\
\hline $\boldsymbol{R}^{2}$ (New Product performance) & 0.355 & 0.355 & \\
\hline
\end{tabular}

Note: AC: Absorptive Capacity; CIN: Collaborative innovation networks; NPP: New Product Performance; T-values are in parentheses. 
Figure 2. Plots of Moderation findings

a) Collaborative innovation networks and absorptive capacity with product innovation capability

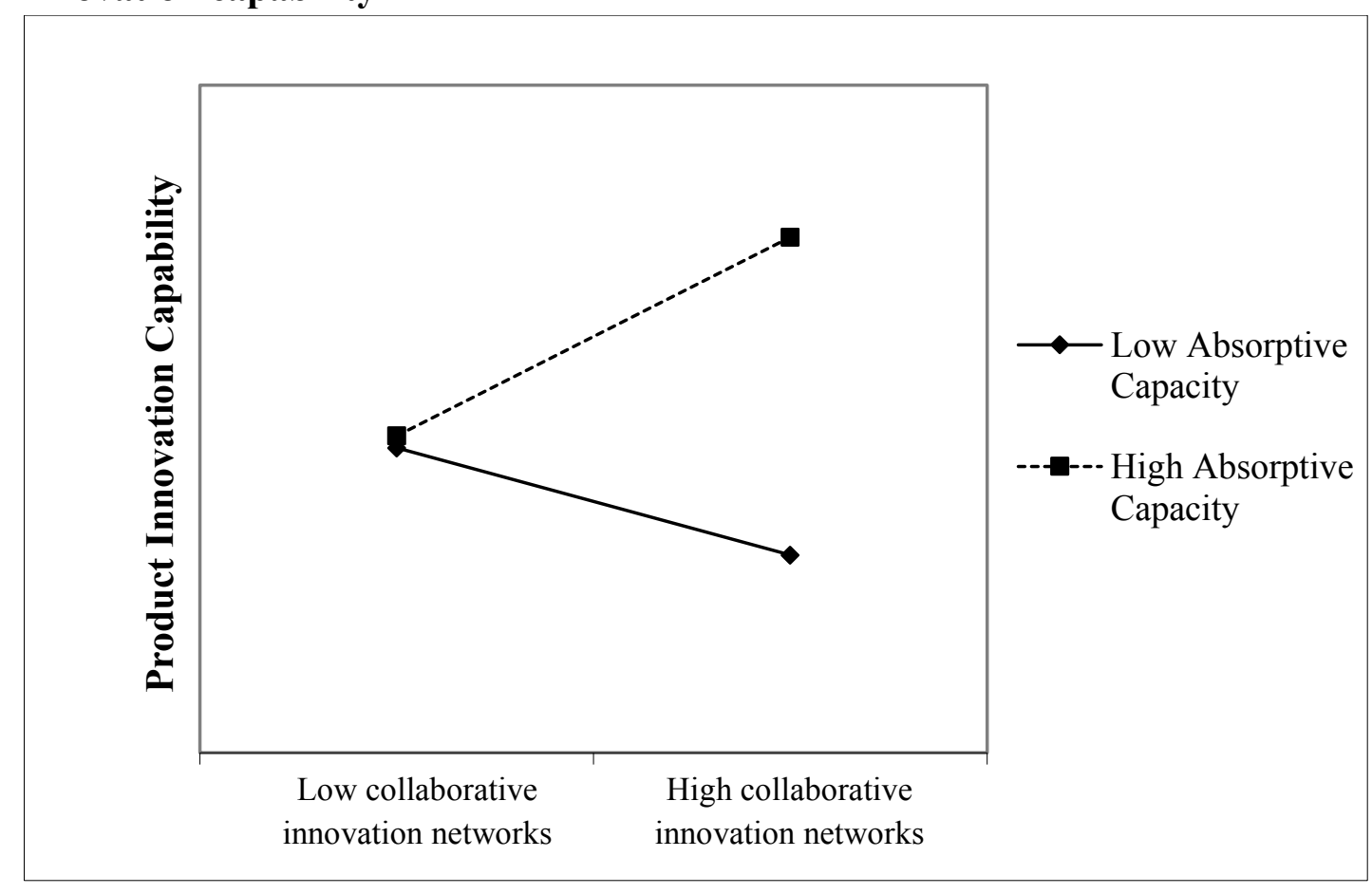

c) Collaborative innovation networks and absorptive capacity with process innovation capability

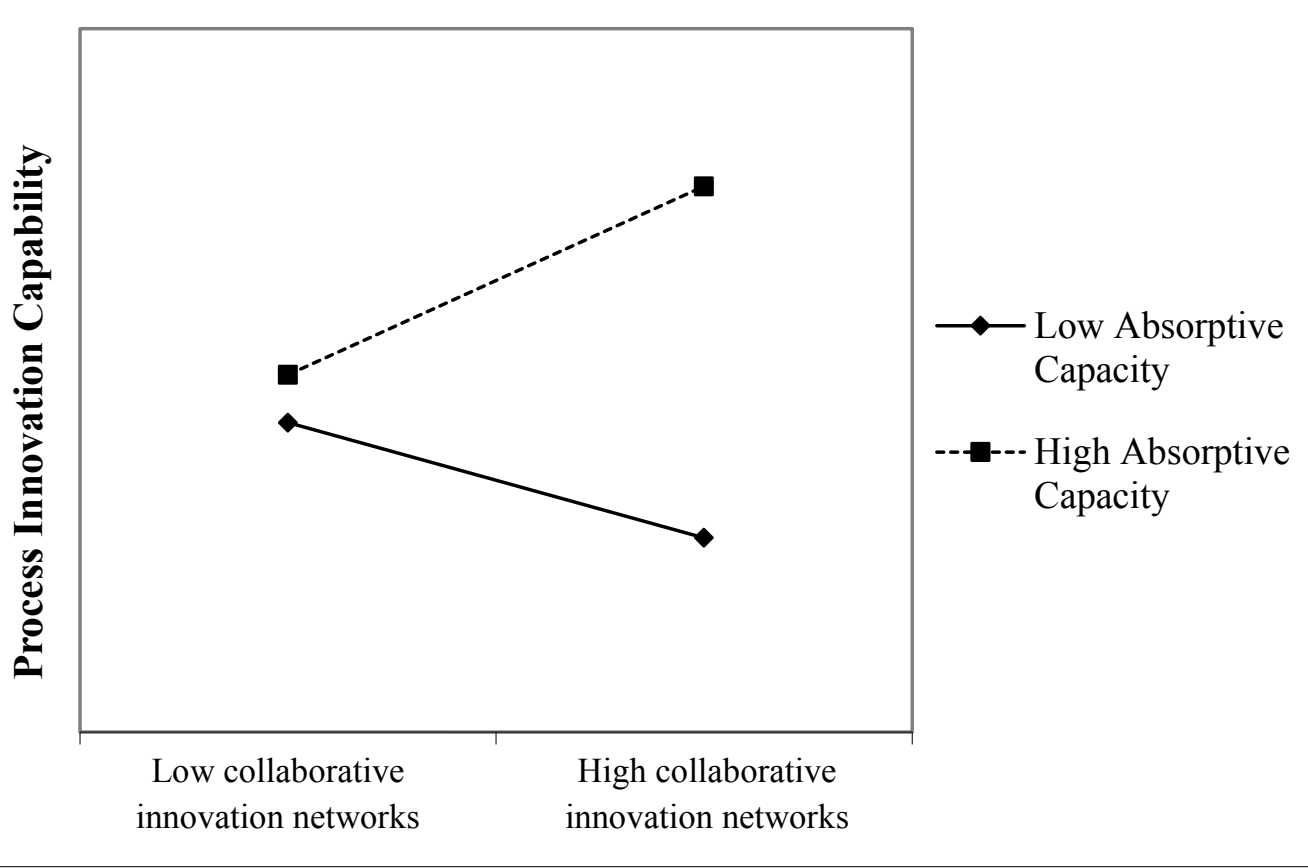


Appendix 1. Items, Codes, Loadings, and Cronbach's Alphas

\begin{tabular}{|c|c|c|}
\hline \multicolumn{3}{|c|}{$\chi^{2}=1329.91 ; d f=866 ;$ IFI $=0.932 ;$ TLI $=0.925 ;$ CFI $=0.932 ;$ and $\mathrm{RMSEA}=0.046$} \\
\hline Constructs & Indicators & Loadings \\
\hline \multirow{6}{*}{$\begin{array}{l}\text { New Product } \\
\text { Performance } \\
(\mathbf{0 . 8 4 9 )}\end{array}$} & How well the organization met the following goals for its new products: & \\
\hline & Met sales growth goals & 0.83 \\
\hline & Met market share goals & 0.84 \\
\hline & Return on investment & 0.70 \\
\hline & Customer acceptance and satisfaction & 0.70 \\
\hline & Development costs* & -- \\
\hline \multirow{4}{*}{$\begin{array}{l}\text { Collaborative } \\
\text { innovation } \\
\text { networks } \\
(0.829) \\
\end{array}$} & Collaboration with suppliers & 0.81 \\
\hline & Collaboration with customers & 0.80 \\
\hline & Collaboration with competitors & 0.62 \\
\hline & Collaboration with research institutes and universities & 0.75 \\
\hline \multirow{4}{*}{$\begin{array}{l}\text { Worker } \\
\text { Knowledge } \\
(0.916)\end{array}$} & The general knowledge level of our first-line workers is high & 0.89 \\
\hline & The overall technical knowledge of our first-line workers is high & 0.86 \\
\hline & The general educational level of our first-line workers is high & 0.81 \\
\hline & The overall job competence of our first-line workers is high & 0.87 \\
\hline \multirow{4}{*}{$\begin{array}{l}\text { Manager } \\
\text { Knowledge } \\
(\mathbf{0 . 9 0 8 )}\end{array}$} & The knowledge of our managers is adequate when making business decisions & 0.88 \\
\hline & The knowledge of our managers is adequate when dealing with new technologies & 0.86 \\
\hline & The knowledge of our managers is adequate when managing daily operations & 0.85 \\
\hline & The knowledge of our managers is adequate when solving technical problems & 0.79 \\
\hline \multirow{5}{*}{$\begin{array}{l}\text { Communications } \\
\text { Network } \\
(\mathbf{0 . 8 7 9 )}\end{array}$} & The communications between supervisors and their subordinates are extensive & 0.81 \\
\hline & The communications among functional areas are extensive & 0.85 \\
\hline & The communications among functional areas are frequent & 0.83 \\
\hline & The communications between supervisors and their subordinates are frequent & 0.73 \\
\hline & The communication of new ideas from one department to another is extensive* & -- \\
\hline \multirow{6}{*}{$\begin{array}{l}\text { Communications } \\
\text { Climate } \\
(\mathbf{0 . 8 6 2 )}\end{array}$} & Our employees tend to trust each other* & -- \\
\hline & Our employees are supportive of each other & 0.76 \\
\hline & Our employees have strong feelings of belonging to our organization & 0.74 \\
\hline & Our employees share ideas freely with each other & 0.72 \\
\hline & Our employees have no difficulty accepting new ideas & 0.75 \\
\hline & Our employees are willing to accept changes & 0.75 \\
\hline \multirow{7}{*}{$\begin{array}{l}\text { Knowledge } \\
\text { scanning } \\
(\mathbf{0 . 8 8 4 )}\end{array}$} & We seek to learn from tracking new market trends in our industry & 0.82 \\
\hline & We seek to learn from routine search of useful information & 0.71 \\
\hline & We seek to learn from benchmarking best practices in our industry & 0.82 \\
\hline & We seek to learn from trying out new technologies* & -- \\
\hline & We seek to learn from our customers and suppliers & 0.66 \\
\hline & We seek to learn from taking new business opportunities & 0.77 \\
\hline & We seek to learn from conducting $\mathrm{R} \& \mathrm{D}$ activities & 0.72 \\
\hline \multirow{5}{*}{$\begin{array}{l}\text { Product } \\
\text { innovation } \\
\text { capability } \\
(\mathbf{0 . 8 3 0})\end{array}$} & Our firm is able to replace obsolete products* & -- \\
\hline & Our firm is able to extend the range of products & 0.78 \\
\hline & Our firm is able to develop environmentally friendly products & 0.71 \\
\hline & Our firm is able to improve product design & 0.80 \\
\hline & Our firm is able to reduce the time to develop a new product until its launch in the market & 0.70 \\
\hline \multirow{10}{*}{$\begin{array}{l}\text { Process innovation } \\
\text { capability } \\
(\mathbf{0 . 9 0 8 )}\end{array}$} & Our firm is able to create and manage a portfolio of interrelated technologies & 0.66 \\
\hline & Our firm is able to master and absorb the basic and key technologies of business & 0.71 \\
\hline & Our firm continually develops programs to reduce production costs & 0.72 \\
\hline & Our firm has valuable knowledge for innovating manufacturing and technological processes & 0.83 \\
\hline & Our firm has valuable knowledge on the best processes and systems for work organization & 0.79 \\
\hline & Our firm organizes its production efficiently & 0.71 \\
\hline & Our firm assigns resources to the production department efficiently & 0.70 \\
\hline & Our firm is able to offer environmentally friendly processes & 0.65 \\
\hline & Our firm manages production organization efficiently & 0.75 \\
\hline & Our firm is able to integrate production management activities* & -- \\
\hline
\end{tabular}

Note: All items were measured using seven-point scales anchored by $1=$ "strongly disagree" and $7=$ "strongly agree". * = Deleted based on loadings; Cronbach's Alphas are in parentheses. 